$1-1-1977$

\title{
The West Virginia wood furniture industry: characteristics, problems and opportunities for development
}

Samuel M. Brock

Norman T. Hilliard

Follow this and additional works at: https://researchrepository.wvu.edu/ wv_agricultural_and_forestry_experiment_station_bulletins

\section{Digital Commons Citation}

Brock, Samuel M. and Hilliard, Norman T., "The West Virginia wood furniture industry : characteristics, problems and opportunities for development" (1977). West Virginia Agricultural and Forestry Experiment Station Bulletins. 654.

https://researchrepository.wvu.edu/wv_agricultural_and_forestry_experiment_station_bulletins/555 @ WVU. It has been accepted for inclusion in West Virginia Agricultural and Forestry Experiment Station Bulletins by an authorized administrator of The Research Repository @ WVU. For more information, please contact ian.harmon@mail.wvu.edu. 
Blank Page in Original Bulletin 


\section{Authors}

Samuel M. Brock is Professor of Forestry Economics; at the time of this study Norman T. Hilliard was a graduate research assistant in Forestry.

West Virginia University

Agricultural and Forestry Experiment Station

College of Agriculture and Forestry

Dale W. Zinn, Director

Morgantown

In cooperation with

Office of Research and Development

Center for Extension and Continuing Education 
Blank Page in Original Bulletin 


\section{Contents}

Foreword $\quad 5$

$\begin{array}{ll}\text { Summary } & 7\end{array}$

$\begin{array}{ll}\text { Introduction } & 9\end{array}$

$\begin{array}{ll}\text { Scope and Method of Study } & 10\end{array}$

The Industry in West Virginia 11

General Description $\quad 11$

Markets for West Virginia Furniture $\quad 12$

Employment and Labor Conditions $\quad 12$

Lumber Use by the Industry 13

Source of Lumber Purchases $\quad 14$

Procurement of Other Raw Materials $\quad 14$

Transportation 14

State Taxes $\quad 15$

Consulting Services $\quad 15$

Plant Site Selection $\quad 16$

$\begin{array}{ll}\text { Selected Firms in Virginia-North Carolina } & 18\end{array}$

$\begin{array}{ll}\text { Conclusions and Recommendations } & 19\end{array}$ 
Blank Page in Original Bulletin 


\section{Foreword}

The research reported in this bulletin was supported by funds provided under the Hatch Act, as amended August 11, 1965. Support also was provided by the Office of Research and Development, Center for Extension and Continuing Education, West Virginia University.

The authors express their appreciation to the wood furniture manufacturers of West Virginia, Virginia, and North Carolina who gave generously of their time in supplying the data presented in this bulletin. Consultation with Dr. Kenneth L. Shellhammer, formerly of the College of Business and Economics, and Dr. Bruce A. Schick of the Division of Forestry, West Virginia University, helped in designing this study and preparing this publication.

Our appreciation also is extended to the staff of the Forest Products Marketing Laboratory, U. S. Department of Agriculture, Forest Service, for reviewing preliminary drafts of the manuscript, and particularly to Dr. Gilbert P. Dempsey for his helpful comments on earlier drafts of this bulletin. 
Blank Page in Original Bulletin 


\section{Summary}

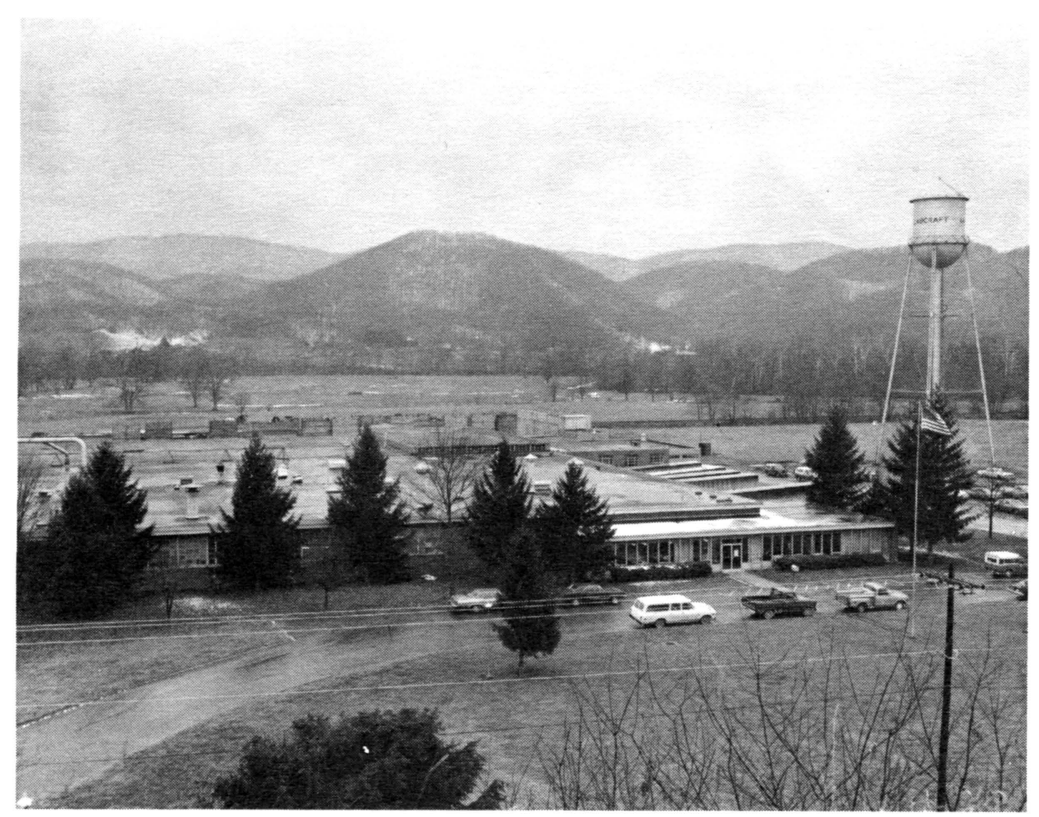

Courtesy by Labcraft, Inc., Beverly, W. Va.

The findings of this bulletin are based upon personal interviews conducted in 1973 with owners or managers of 33 wood furniture firms in West Virginia, a complete canvass of the industry, and with executives of seven large firms in the Virginia-North Carolina furnituremanufacturing complex centered near High Point, North Carolina. Objectives of this research were to: (1) describe the characteristics and problems of the wood furniture industry in West Virginia, (2) assess the attitudes of executives of several large furniture firms in Virginia and North Carolina toward locating new production facilities in the state, and (3) recommend actions for improving programs of public assistance directed toward the industry.

In 1972, the West Virginia wood furniture industry employed 1,602 workers and sold products worth $\$ 27,181,200$. The industry was highly concentrated, the five largest firms-those employing more than 50 workers-accounting for about 82 percent of the dollar volume of sales. The remainder of the industry consisted of relatively small enterprises.

Only one-third of the labor force was composed of skilled workers; 23 percent was considered semi-skilled and 44 percent unskilled. However, 16 firms reported that they had experienced difficulties in obtaining labor with the level of skills required, and that statesupported vocational training programs in woodworking were needed. 
In 1972, the West Virginia wood furniture industry purchased 12,555 thousand board feet of rough-cut lumber or about 3 percent of the year's state sawmill output.

Even though furniture firms in West Virginia were located in the midst of the Appalachian hardwood lumber production region, they experienced difficulties in obtaining lumber of the desired species and grade. This was probably because these firms obtained almost twothirds of their lumber directly from sawmills. The services of wholesalers, who perform the function of concentrating significant volumes of graded lumber, might prove helpful in alleviating this problem.

Executives of all seven firms studied in the Virginia-North Carolina area thought that the availability of skilled and unskilled labor was crucial when considering a location for a new plant. Transportation facilities, and ready access to regional markets, also were considered very important. The availability of raw materials was less important than the other factors.

All of the executives interviewed had negative impressions about West Virginia as a site for new production facilities. However, these did not seem to be based upon factual information. Provision of facts on furniture-making opportunities in the state would be beneficial.

Recommendations made in this study include undertaking research on: (1) the West Virginia labor force, (2) transportation from sites in West Virginia to regional markets, and (3) the system of lumber distribution from West Virginia sawmills to secondary manufacturers. Services of extension workers are needed to assist in establishing labor training programs, and for consultation on production and marketing problems. Extension workers should provide communication between researchers and practitioners in the industry so that significant problems can be readily identified and solutions sought. The state's Industrial Development Division should work to reinforce these efforts. 


\title{
The West Virginia Wood Furniture Industry: \\ Characteristics, Problems, and Opportunities for Development
}

\author{
Samuel M. Brock and Norman T. Hilliard
}

\section{Introduction}

Except for construction and shipping, the furniture industry is the most important secondary wood-using industry in the United States. ${ }^{1}$ In 1970, 69 percent of the 4.7 billion board feet of lumber used in manufacturing went into furniture. ${ }^{2}$

Even though West Virginia is a leading producer and exporter of hardwood lumber ${ }^{3}$-an important input in furniture manufacture furniture making has never been an important economic activity in the state. If existing furniture firms could expand their operations, or if new firms could be attracted to the state, the timber resource base would make a more significant contribution to the West Virginia economy. Through a growth oriented furniture industry, the state could shift from a forest economy which is largely extractive in nature to one manufacturing a higher valued product.

Previous studies have shown that there are opportunities for location of new furniture plants in West Virginia. ${ }^{4}$ However, descriptive information on the characteristics of the present industrv, and its

1H. F. Kaiser and L. M. James, The Michigan Furniture Industry and Its Utilization of Wood Products, Agr. Expt. Sta. Res. Bull. 21 (East Lansing: Mich. State Univ., 1969), p. 3.

2U. S. Dept. of Agriculture, Forest Service, The Outlook for Timber in the United States, For. Resour. Rep. No. 20 (Washington, D. C.: U. S. Government Printing Office, 1973), p. 169.

${ }^{3}$ D. E. Nelson, W. W. Christensen, W. H. Reid, and N. D. Jackson, Marketing Practices of West Virginia Lumber Producers, Agr. Expt. Sta. Bull. 507 (Morgantown: W. Va. Univ., 1965), pp. 5, 15.

4P. R. Hagenstein, Timber Industry Opportunities in Selected Areas of West Virginia, U. S. Forest Serv. Res. Paper NE-28 (Upper Darby, Pa.: Northeast. Forest Expt. Sta., 1964), 72 pp. Also see Fantus Area Research, Inc., A Study of the Potential for Furniture and Other Wood Industries in the Monongahela Power Company Service Area (New York, 1962), 174 pp. 
problems in plant operation and marketing, was not available. Nor had an assessment been made of the attitudes of furniture producers in important out-of-state centers of manufacture toward locating new plants in West Virginia. Such information is needed by researchers, extension workers, industrial developers, and others assisting the West Virginia wood furniture industry. Obtaining it was the major purpose of this study.

The specific objectives of this research project were to:

1. Describe the present characteristics of the wood furniture industry in West Virginia, and ascertain current operating problems and barriers to plant expansion.

2. Determine what factors are important in influencing plant location decisions of several large furniture producers in the Virginia-North Carolina furniture-manufacturing complex, and ascertain reasons these firms have for not locating new plants in West Virginia.

3 . Evaluate the results obtained in (1) and (2), and make recommendations for improving research, extension, and industrial development programs directed toward assisting the West Virginia wood furniture industry.

\section{Scope and Method of Study}

To meet the first study objective, a complete survey was made of wood furniture firms in West Virginia during the summer of 1973. Thirtythree such firms were identified with the aid of a directory of the secondary wood-using industry in the state. ${ }^{5}$ A questionnaire was prepared, and personal interviews were conducted with firm owners or managers. All data gathered pertained to the firms' operations for the 1972 calendar year.

To satisfy the second research objective, personal interviews were conducted with executives of seven selected firms in the Virginia-North Carolina furniture-making complex. Since budget and time restrictions permitted study of only a few out-of-state firms, the researchers decided that those selected for investigation should be prominent in their field, capable of expansion, and considering growth in the near future. The firms were identified, selected, and data were collected with a prepared questionnaire in August, 1973.

As the study objectives suggest, the information gathered for this report was largely descriptive. Only limited attempts were made to

- establish causal relationships, as, for example, between factors influencing location decisions and firm size.

${ }^{5}$ W. Va. Dept. of Natural Resources, Division of Forestry, The Secondary Forest Industry of West Virginia, 1972. (Charleston, W. Va., 1972), pp. 9-12. 
While the findings for West Virginia were based upon a complete canvass, the results for the Virginia-North Carolina area were obtained from a few selected firms, and are not necessarily representative of the industry.

\section{The Industry in West Virginia}

General Description. The 33 firms surveyed in West Virginia may be classified into the following basic groups-those producing nonupholstered wood household furniture (20), upholstered wood household furniture (6), and institutional furniture (7). ${ }^{6}$ Fifteen of these firms were organized as single proprietorships, while the remaining 18 were corporations, of which only two were publically owned, the remainder being family-held or private.

Only five firms operated more than one plant. Three of these operated one or more production units outside the state. The five multiplant operations produced non-upholstered wood household or institutional furniture exclusively.

That almost 90 percent of the firms surveyed had been in business for longer than five years suggests that the industry has experienced a considerable degree of stability. However, since four firms were established during the recent past, there appears to be no significant barrier to the entry of new enterprises.

In 1972, the West Virginia wood furniture industry employed 1,602 workers, all but 30 full time. Firms producing non-upholstered furniture were the largest employers with 1,171 full-time workers. Firms manufacturing upholstered furniture employed 196, and those producing institutional furniture 205. In terms of number of employees, the firms surveyed in this project were relatively small. Fourteen employed fewer than five workers. Only five firms émployed more than 50.

In 1972, the industry had total gross sales of $\$ 27,181,200$. Sales of firms employing more than 50 workers accounted for 82 percent of this total.

Fifteen of the state's furniture firms spent nothing on advertising, and an additional five spent less than 1 percent of their gross sales receipts on this activity. Minimal expenditures for advertising and promotion are characteristic of firms facing highly elastic demand schedules in highly competitive industries. ${ }^{7}$

\footnotetext{
${ }^{6}$ For purposes of this study, institutional furniture is public building and wood office furniture. Two firms manufacturing store fixtures were included in this group.

${ }^{7}$ For a discussion of the relationship between the percentage of sales receipts spent on advertising and elasticity of demand, see L. G. Telser, "How Much Does It Pay Whom to Advertise," Amer. Econ. Rev., Vol. LI, No. 2 (1961), pp. 194-205.
} 
Firm managers were queried to obtain their judgment on whether the furniture they manufactured was high, medium, or low in price and quality. Seventeen classified their products in the medium price range, 12 felt their prices were relatively high, and four were of the opinion that their prices were relatively low. While most firm managers believed they were selling their products at a medium price, 25 felt their products were relatively high in quality.

Quality and price play an important role in determining the market for a firm's product. Style and changes in style also are important. Thirteen firms relied on magazines for design changes. Other sources, in order of importance, were: owner's ideas, designers, customer's ideas, furniture expositions, salesmen's ideas, history books (for reproductions), government specifications, and general experience.

Markets for West Virginia Furniture. The East Coast provided the major market for West Virginia furniture. The state's firms received over two-thirds of their total gross sales receipts from customers in that region. Firm owners or managers often were unable to identify specific destinations for the furniture they shipped. New York was the most important of those identified.

Sales made directly to consumers accounted for 44 percent of total receipts. Thirty-seven percent of total gross sales were made to wholesalers, while 19 percent were made to retailers.

Channels through which sales were made varied by size of firm and type of furniture produced. For example, firms with four or less employees received 77 percent of their gross sales receipts directly from consumers. This percentage is very high compared to direct sales by larger firms in the industry. Firms selling non-upholstered furniture tended to divide their sales evenly between wholesalers and consumers. On the other hand, firms producing upholstered furniture received 96 percent of their sales receipts from retail stores. Firms manufacturing institutional furniture differed from the other types in that the bulk of their sales were made directly to general contractors.

Only five firms experienced problems selling their furniture through established market outlets. Two had problems of intensive competition, while the remaining three cited a general slowdown in business as a factor.

Employment and Labor Conditions. In 1972, the full-time labor force of the industry was comprised of 69 percent male and 31 percent female workers. Firms producing non-upholstered furniture hired proportionately more females than did other segments of the industry; 36 percent of their labor force was women. On the other hand, females made up only 5 percent of the labor force for firms producing institutional furniture. Such differences in the composition of the labor 
force may be due to fundamental differences in technology and resultant skill requirements.

Firm owners or managers grouped their employees into three skill-level categories: skilled, semi-skilled, and unskilled. Thirty-three percent of the labor force was considered skilled, 23 percent semiskilled, and 44 percent unskilled. Firms producing non-upholstered furniture had the lowest skill-level requirements; 55 percent of their employees were unskilled. Firms manufacturing upholstered furniture required a higher level of skilled employees; only 18 percent of their work force was unskilled. Firms producing institutional furniture required the highest skill level; 91 percent of their employees were considered skilled.

To manufacturers outside the state looking for new plant sites, the level of unionization of workers is probably important. Of the $\mathbf{3 3}$ firms in the state, only four were unionized. However, these four firms employed 69 percent of the work force of the industry. The unions were the United Brotherhood of Carpenters and Joiners of America and the United Steelworkers of America. Of the four unionized firms, two had experienced work stoppages in the preceding five years, with the longest stoppage lasting two weeks.

Only seven firms had experienced problems with their labor force other than strikes. These problems included a high rate of employee turnover and high absenteeism.

Sixteen firms experienced difficulties in obtaining labor with the type of skills required. Managers of these firms felt this problem could be corrected through state-supported vocational training programs in wood working.

Lumber Use by the Industry. Almost all the lumber used by the West Virginia wood furniture industry in 1972 was purchased. Two firms operated their own sawmills, which produced only 310 thousand board feet. The industry purchased 12,555 thousand board feet of rough-cut lumber. Seventy-nine percent of this was oak, with smaller amounts of yellow-poplar, maple, and other hardwoods. Softwood species were purchased in insignificant amounts. The industry also bought 167 thousand board feet of dimension stock.

The five firms employing more than 50 workers bought 91 percent of the total volume of rough-cut lumber purchased. Firms manufacturing non-upholstered furniture bought 10,453 thousand board feet. Firms producing other types of furniture purchased much smaller amounts.

Eighty-five percent of the total volume of lumber purchased by the industry was No. 2 common grade. Seventy-seven percent of the total was green, 20 percent kiln dried, and 3 percent air dried. Whereas about 80 percent of the lumber bought by firms producing non-upholstered 
or institutional furniture was green, over half of that purchased by firms manufacturing upholstered furniture was kiln dried.

Source of Lumber Purchases. The industry purchased lumber from four basic sources: sawmills, wholesalers, commission agents, and retail yards. Almost two-thirds of the lumber purchased was acquired directly from sawmills. Commission agents handled 20 percent of the volume purchased, while wholesalers provided 14 percent. Retail yards supplied only 2 percent of the volume purchased.

Small firms, those with fewer than five employees, purchased 87 percent of their requirements from retail yards. Larger firms relied mainly on other sources of supply. Firms manufacturing nonupholstered furniture, as well as those producing upholstered, purchased almost three-fourths of their requirements directly from sawmills. On the other hand, firms producing institutional furniture obtained 82 percent of the lumber they purchased from commission agents.

Of the 12,555 thousand board feet of lumber purchased by West Virginia furniture firms, 88 percent was supplied by in-state sources. Most of the remainder was obtained from neighboring states such as Kentucky and Pennsylvania. Foreign imports amounted to only 60 thousand board feet.

Twenty-two of the 33 firms in the state experienced difficulties in obtaining lumber of the desired species and grade. Such difficulties posed problems to the larger firms as well as the smaller ones. In addition, there was much confusion on grading. Lacking the services of a trained lumber grader, firms were unable to verify that the lumber they received was composed of the grades they ordered.

Other difficulties with lumber supply included high prices, a shortage of available kiln space in the state, and in the case of foreign imports, the declining value of the dollar abroad.

Procurement of Other Raw Materials. Almost one-third of the firms surveyed had experienced some difficulty in obtaining non-lumber raw materials. The most frequently mentioned problem was a scarcity of special hardware items. A few firms had difficulty in obtaining hardboard and particleboard. Other difficulties included slow deliveries and a scarcity of corrugated paper for packaging.

Despite these difficulties, most firms reported that they were able to secure prompt services from their suppliers in solving manufacturing and other problems.

Transportation. Trucks were by far the major source of transportation, both for raw materials and for finished products. All of the firms studied indicated that not more than 5 percent of their raw materials, 
in terms of cost, were shipped by rail. In terms of total sales receipts, the firms delivered 91 percent of their furniture to purchasers by truck. Only eight of the 33 firms surveyed experienced any difficulty in obtaining transportation. The major problem was a delay in deliveries of required raw materials. Other problems included the lack of ready availability of railroad cars, the reluctance of some motor carriers to travel in the state, and lost shipments.

Although there has been some contention that roads in West Virginia are poorly suited for truck transportation, only four firms indicated that highways needed improvement. Managers of these firms believed that more interstates were required, and that access roads needed improved capacity. The owner of one firm, on the other hand, felt that interstates would destroy the uniqueness of the state, and thus have an adverse effect on his market for furniture from the West Virginia hills.

State Taxes. Nineteen of the owners or managers interviewed were of the opinion that the West Virginia tax structure discouraged growth of the furniture industry. Fifteen of these felt that the business and occupation tax, which is levied on gross sales, was too high to allow a small industry with a varying cost structure (and presumably a small profit margin) to achieve growth. Since businessmen are inclined to complain about taxes, this finding is hardly surprising. Indeed, some evidence indicates that the furniture industry might pay higher taxes under some alternative to the current business tax on gross sales, such as a value added tax. ${ }^{8}$ Probably the aspect of the business and occupation tax that has hindered growth is its lack of predictability rather than its magnitude. ${ }^{9}$ There have been frequent and capricious rate changes under this tax which have created a great deal of uncertainty about future tax liabilities. This uncertainty has handicapped future planning for capital expansion and new plant development.

Consulting Services. Almost half of the firms surveyed indicated that they would be interested in obtaining consultation from West Virginia University or other state agencies for aid in solving manufacturing and marketing problems. The most frequently mentioned type of consultation related to aid in industrial engineering and merchandising. Other services desired included a training program for labor, a survey of raw

8J. A. Papke, The State Business Tax Structure: A Quantitative Analysis for Policy Deliberations, unpublished report to the Joint Committee on Government and Finance, W. Va. Legislature (Charleston, W. Va., Sept. 12, 1966).

${ }^{9}$ D. R. Leyden, An Economic Analysis of a Tax Alternative to the Current Turnover Tax on Business in West Virginia: A Simulation Study, 1967-1969, PhD dissertation (Charlottesville: Univ. of Va., 1976), pp. 287-91. 
material sources, aid in setting up a quality control system, assistance in compiling a directory of hardware suppliers, aid in inspecting lumber grades, and assistance in handling personnel problems.

Plant Site Selection. Wood furniture firms in West Virginia had many reasons for the locations they chose for plant sites (Figure 1). These were most frequently selected on the simple basis of their proximity to the hometown of the owner or founder. The availability of a building suitable for furniture manufacturing was the second most important factor influencing location choice.

Small firms (four or less employees) gave fewer reasons for their plant site selections than larger firms (Figure 1). The outstanding factor mentioned by the small firms was that their business was located at the owner's home. Other reasons included the availability of a building, ability to operate without noise complaints, and just a feeling of good luck in that area.

Larger firms expressed many reasons for their site selection choices (Figure 1). The most frequent responses were: (1) availability of a building, (2) availability of labor, (3) availability of lumber, (4) availability of a plant site, and (5) owner's home.

Prospects for expansion of existing furniture firms in West Virginia appear promising. Eighteen of the $\mathbf{3}$ firms studied indicated that they were planning to enlarge their operations in the near future. Almost all of these firms planned expansion at their present plant sites; one firm planned to move to a new site in the state.

Owners or managers of the study firms were asked where they would locate if they had the financial resources to build a new plant anywhere. ${ }^{10}$ Twenty-five firms indicated that they would remain at their present locations and three indicated they would move but remain in West Virginia. One manager felt that it would be profitable to relocate in North Carolina in order to have a labor pool skilled in furniture manufacture to draw upon. The manager of another firm favored Tennessee. Two firms indicated that Virginia would be best for their operations because of its aggressive industrial development agency, and the fact that less strip mining had been done there than in West Virginia.

An inquiry was made to determine what information or services would be helpful to a furniture manufacturer for investigating a new plant site. ${ }^{11}$ Managers of 18 firms thought a labor survey would be

10There was one non-response to this inquiry.

${ }^{11}$ Some firms gave several responses to this question. 
Figure 1. Number of Firms in the West Virginia Wood Furniture Industry Expressing Reasons for the Selection of Their Present Plant Sites, by Employment Size Class (Some firms expressed more than one reason).

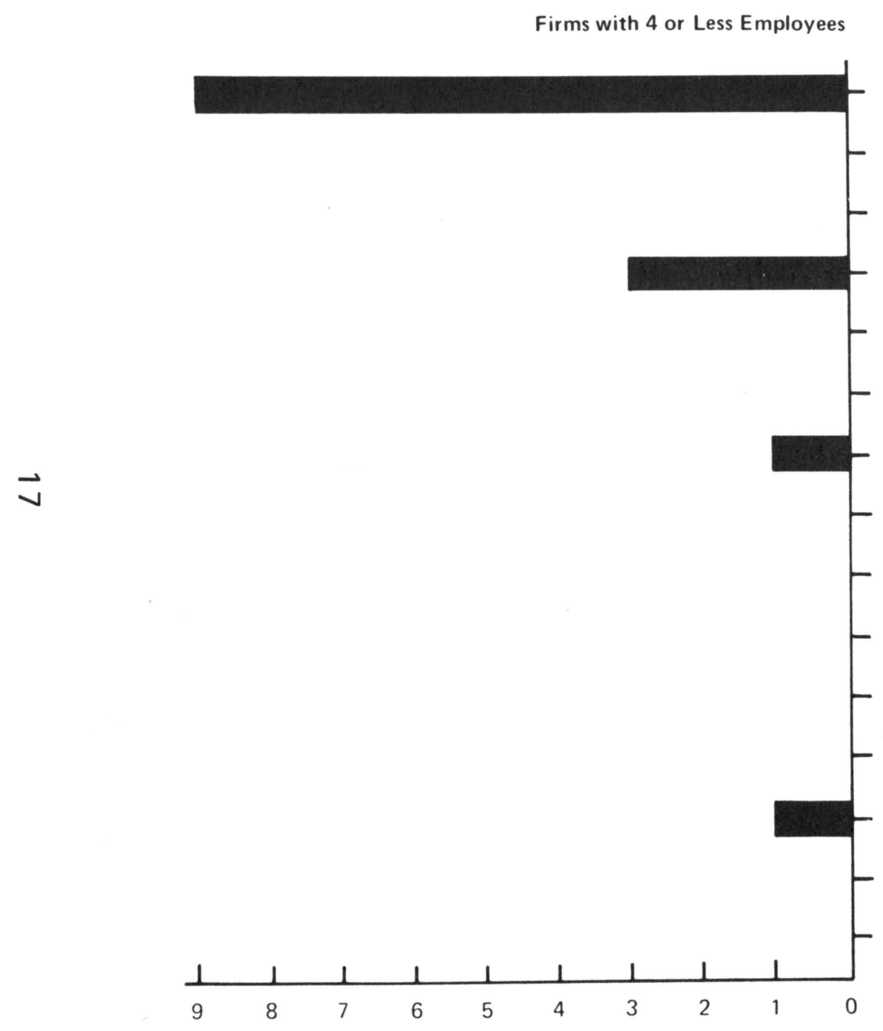

Reasons

Owner's Home

Center of Salesman's Territory

Own Lumber Company

Building Available

Labor Available

Expansion Possible

No Noise Complaint

Lumber Available

Capital Available

Centrally Located Site Available

Low Wage Rates

Good Luck Here

Esthetic Reasons

Good Business Area
Firms with 5 or More Employees

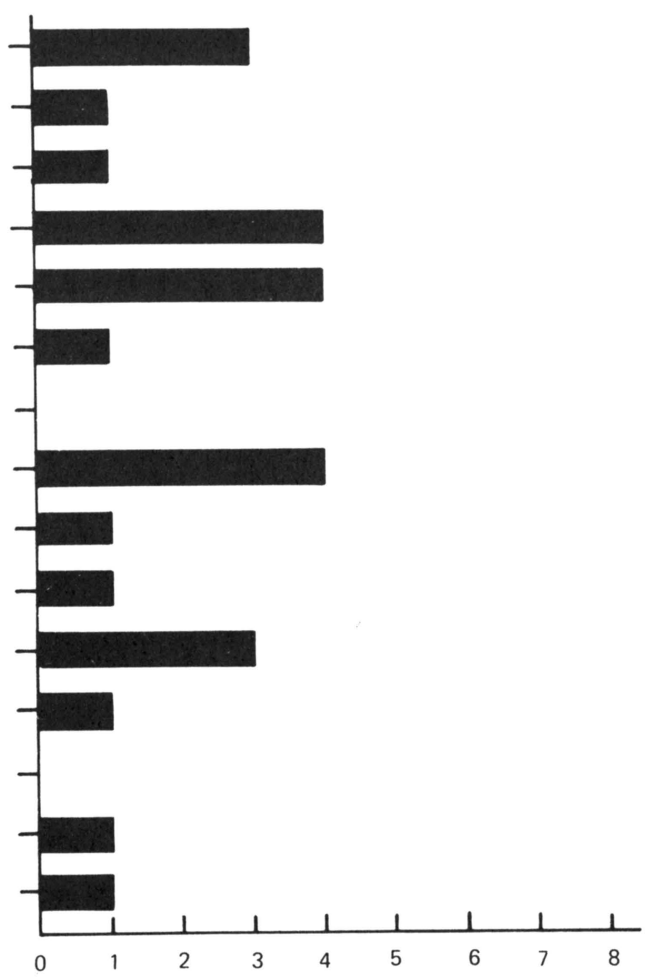

Number of Firms 
helpful. Eleven interviewees believed information on the availability of lumber would be useful, while 10 mentioned that a transportation survey was important.

Since many furniture firms are clustered near High Point, North Carolina, and these firms may realize economies of agglomeration, the interviewees were asked if they thought it was of any advantage for furniture manufacturers to locate in close proximity to one another. Seventeen believed there was an advantage. The outstanding reason given was the availability of a skilled labor pool for all manufacturers to draw upon.

\section{Selected Firms in Virginia-North Carolina}

All seven of the firms selected for study in the Virginia-North Carolina area were corporations, three of them publically owned. The remainder were tightly held family or other private corporate ownerships.

The firms operated as few as three plants to as many as 30 , mostly in Virginia-North Carolina. Other plants were located in Alabama, Arkansas, Colorado, Florida, Georgia, Illinois, Michigan, Mississippi, Pennsylvania, and South Carolina.

All of the firms had been in the furniture business for relatively long periods of time, ranging from 25 to 84 years. All produced both upholstered and non-upholstered furniture. One firm produced institutional furniture as well.

During the early 1970s a labor shortage limited the opportunities for expansion of the furniture industry in Virginia-North Carolina, a point stressed by the first executive interviewed; executives at all the other firms were in complete agreement with this assessment. One firm had constructed a new plant near its present facilities, but was unable to operate it due to the shortage of labor, Some firms, therefore, were looking toward other regions for expanded facilities. Executives of these firms believed that other regions for plant location also were attractive because currently distant markets could be served from regional centers at reduced transportation costs.

Six firms had expanded their operations during the preceding five years through mergers or construction of new plants. Most of their additional plant capacity was acquired or constructed in Virginia-North Carolina. These sites offered the advantage of proximity to current management, a factor which seemed to outweigh other considerations. Expanded facilities also were located in Arkansas, Georgia, Michigan, Mississippi, and New York. Although availability of labor was the primary factor influencing decisions to locate in these states, two executives suggested that good transportation facilities also were important. 
Six firms planned to expand their operations in the near future. Despite the labor shortage, four of them had decided to construct new facilities in Virginia-North Carolina. Although the availability of labor-C was crucial, the interviewees felt they would be able to meet their requirements by bidding for the services of workers employed by competitors. The remaining two firms planned to locate new plants in Mississippi and Oklahoma, primarily because labor was more readily available there. Those sites also offered accessibility to regional markets.

The seven furniture firm executives were asked what factors they considered important in making new plant location decisions. All thought the primary consideration was the availability of skilled and unskilled labor. Three executives mentioned that good transportation facilities were essential. Four were of the opinion that accessibility to regional markets was important. Two suggested the importance of the availability of raw materials.

Only one of the seven firms studied had ever considered West Virginia as a potential site for production facilities. Executives of this firm decided against location in the state because of its high degree of unionization, and associated fear of a high incidence of work stoppages.

All of the executives queried about West Virginia as a possible site for location of new plants had negative impressions. Three believed they would have to train their labor force if they located in the state. Two felt that sites in West Virginia were too far removed from the head office for management to control the enterprise. Two thought it would be difficult to get top management to relocate in West Virginia. Other factors influencing decisions not to locate there included a poor labor image, with unions and high wages, and lack of advantage in access to markets over existing plants in Virginia-North Carolina.

An inquiry was made to determine what measures West Virginia could take to attract furniture firms to the state. The executives thought that it would be helpful if industrial developers were more aggressive in furnishing information on furniture-making opportunities. Such information should include data on labor, transportation, and the availability of financing.

\section{Conclusions and Recommendations}

In 1972, furniture manufacturing made a minor contribution to the West Virginia economy. It never has been an important economic activity in the state. However, future development seems possible if problems currently confronting the industry are satisfactorily resolved.

The returns to current programs of public assistance to the West Virginia furniture industry, compared to alternative opportunities for 
investment, were not evaluated in this study. Thus, there is no basis for recommending that the level of expenditure be increased. However, it the programs are continued at their present levels, information collected in this project should be useful for improving them. The following suggestions are directed toward accomplishing this goal.

With the aid of findings of previous studies, areas in West Virgini which offer opportunities for expansion of the furniture industry should be identified. ${ }^{12}$ A detailed study of the labor force in these areas should be undertaken. This would include determining the size of the unemployed labor force, its composition, level of education, previous experience, and suitability for training in woodworking. Studies of the causes of absenteeism and labor turnover in established plants also should be made.

West Virginia is favorably located with respect to large population centers of the East and Midwest. In 1973, it was reported that more than half of the nation's people reside and more than half of the nation's income is earned within a 500-mile radius of the state's geographic center. ${ }^{13}$ Thus, furniture firms located in West Virginia should have ready access to many of the nation's major markets. A study of transportation facilities to these markets and transportation costs would be useful both for firms currently operating in the state and to those viewing it as a possible site for plant location. The study should determine transportation costs for raw materials as well.

The findings of this project indicate there are problems in the West Virginia lumber distribution system regarding in-state lumber users. A study of this system should be made, and causes of these problems identified. That the state's furniture firms experienced difficulties in obtaining lumber may be partially explained by the fact that they purchased almost two-thirds of their requirements directly fror sawmills. The opportunities and advantages of an enlarged lumbel wholesaling function would be a fruitful area for exploration.

West Virginia University has substantial resources for solvinc production and marketing problems for the state's furniture industry Increased research efforts could be made in quality control, wooc seasoning, finishing, merchandising, and other problem areas ir response to industry requests. Available resources would support the research needs of an expanded industry.

Although over half of West Virginia's furniture firms mentioned tha the state's tax structure discouraged growth, new tax studies do no seem warranted. In general, those who have attempted to ascertain thi

12P. R. Hagenstein, op. cit. note 4.

13W. Va. Dept. of Commerce, Industrial Development Division, West Virginic Industrial Data File, unpublished report (Charleston, W. Va., 1973). 
effect of taxes on plant location have concluded that the size of the tax bill is not a major determinant of plant location decisions. ${ }^{14}$ Rather, it is uncertainty about future tax liabilities due to frequent and capricious rate changes that discourages firms from making long-term investments. ${ }^{15}$ The resolution of this problem rests with the state legislature.

Services of the Cooperative Extension Service, West Virginia University, could make an important contribution in improving the profit position of furniture firms currently operating in the state. Extension workers have the capability of providing the industry with information on state and federal labor training programs, and assisting in establishing short courses in woodworking and lumber grading. Assistance of this nature has long been provided for the logging and sawmilling (primary) sector of the wood industry. Functioning in a similar capacity for the secondary sector, extension personnel could act as a liaison between furniture firms and research workers so that significant problems in production and marketing could be identified and solved. Extension specialists also could provide consultation on efficient plant layout, aid in setting up wage-incentive programs, and assistance in establishing quality control systems. Study findings suggest that the larger firms (five or more workers) would be most receptive to and capable of using such assistance.

Study findings have shown that seven large furniture firms in Virginia-North Carolina had almost a total lack of interest in West Virginia as a potential site for production facilities. However, the interviewers feel that these firms had little, if any, factual information about the state. Executive opinions were based mainly on hearsay and personal impressions. These impressions could be modified through provision of pertinent information. The state's poor labor image, for example, is probably due to widespread publicity concerning the mining industry, which has experienced frequent strikes and other labor problems. In a 1971 study, it was found that when the mining work stoppage record was subtracted from the overall state total, the incidence of work stoppage of the remainder gave the state a record which was about average for the nation. ${ }^{16}$ Provision of such information to manufacturers having a distorted image of industrial relations in West Virginia would be most beneficial.

It would be helpful if the Industrial Development Division of the West Virginia Department of Commerce prepared a brochure on furniture-manufacturing opportunities in the state. In addition to

14J. F. Due, "Studies of State-Local Tax Influence on Location of Industry," National Tax Journal, Vol. XIV, No. 3 (1961), pp. 163-73.

15D. R. Leyden, op. cit. note 9.

${ }^{16} \mathrm{~K}$. Dix, An Analysis of West Virginia Work Stoppages, Inst. for Labor Stud. Res. Series 5 (Morgantown: W. Va. Univ., 1971), p. 59. 
identifying sites which afford promising opportunities, available information on the labor force, transportation, suppliers of raw materials, and arrangements for financing should be included. This brochure should be prepared in close cooperation with researchers working on industry problems, so that efforts are coordinated and new findings incorporated as they become available.

Many West Virginia firms were interested in procuring detailed information on furniture marketing. Such information is compiled by the Southern Furniture Manufacturers Association (SFMA) and is made available to members on a regular basis. Many other services also are provided by SFMA. Annual membership dues are based upon a sliding scale, depending on dollar sales volume, with minimum dues of 300 dollars per year. West Virginia furniture makers should be encouraged to join such associations.

Recommendations made in this study are summarized in Table 1, which also indicates the group that should undertake the recommended action. The successful implementation of these recommendations should enhance the prospects for expansion of the West Virginia wood furniture industry. 
Table 1. Recommended Actions for Assisting the West Virginia Wood Furniture Industry, by Initiator.

West Virginia University: Division of Forestry, Office of Research and Development, Bureau of Business Research and other units

West Virginia University:

Cooperative Extension Service

West Virginia Department

of Commerce:

Industrial Development Division

West Virginia Wood Furniture Manufacturers
1. Conduct research on the labor force in areas offering opportunities for expansion of the furniture industry.

2. Make a study of transportation facilities and costs to regional markets.

3. Undertake research on systems of lumber distribution to secondary manufacturers.

4. Act as a service center for solving production and marketing problems upon request of the furniture industry.

5. Provide consultation to the West Virginia Department of Commerce, Industrial Development Division, to aid in the provision of decisionmaking information on furnituremaking opportunities.

1. Provide information on labor training programs and assist in setting up short courses in woodworking and lumber grading.

2. Act as a liaison between the industry and researchers to identify and solve significant problems.

3. Provide consultation on efficient plant layout, aid in setting up wage incentive programs, and assistance in establishing quality control systems.

1. Prepare a brochure on furnituremaking opportunities in West Virginia.

2. Cooperate with researchers in compiling available information on the labor force, transportation, raw material suppliers, etc.

1. Join the Southern Furniture Manufacturers Association (SFMA).

2. Make use of marketing information and other services provided by the SFMA.

3. Contact industrial developers and extension workers to obtain useful information presently available. 
[Blank Page in Original Bulletin] 


\section{[Blank Page in Original Bulletin]}




\section{[Blank Page in Original Bulletin]}

